\title{
Resistance of Aedes as a Vectors Potential for Dengue Hemorrhagic Fever (DHF) in Semarang City, Indonesia
}

\author{
Martini $^{1 *}$, Retno Hestiningsih ${ }^{1}$, Bagoes Widjanarko ${ }^{1}$, Susiana Purwantisari ${ }^{2}$ \\ ${ }^{1}$ Faculty of Public Health, Diponegoro University, Semarang 50275, Indonesia \\ ${ }^{2}$ Faculty of Mathematics and Natural Sciences, Diponegoro University, Semarang 50275, Indonesia
}

Article history:

Submission February 2017

Revised October 2017

Accepted September 2018

*Corresponding author:

E-mail: tinihen65@yahoo.co.id

\begin{abstract}
Dengue Hemorrhagic Fever (DHF) is a significant health problem in Semarang, Indonesia. A Certain type of insecticides has been widely applied beginning in the last decade as an effort to control the mosquito vectors of dengue virus. This practice could lead to increased resistance in mosquito populations toward these types of insecticides. This research aimed to describe the resistance status of Aedes sp. populations in Semarang. A cross-sectional design study was conducted in 2015, with Aedes sp. populations sampled in several villages of Semarang. Field strains of Aedes sp. eggs were collected using ovitraps and larvae from entomological surveys. Mosquito adults were raised from the collected eggs and larvae under standard conditions and used for biochemical assays. ELISA examined Aedes sp. resistance status. The results showed that there was monooxygenase activity in Aedes sp. populations. In quantitative terms, $77.8 \%$ of mosquito samples showed an Optical Density (OD) more than the cut-off point (0.165). Resistance to synthetic pyrethroid insecticide in Aedes sp. mosquitoes population in Semarang may be caused by the mechanism of monooxygenase detoxification enzymes in particular. This case indicated that Aedes sp. has a high capacity as a vector to transmit the dengue virus in Semarang.
\end{abstract}

Keywords: Aedes sp., vector capacity, dengue, Dengue Hemorrhagic Fever (DHF)

\section{Introduction}

In 2010, Indonesia had the highest number of dengue fever cases among the ASEAN countries, with a total of 156,086 cases, with 1,358 deaths due to this disease. In 2011, the number of cases decreased to 49,486, with 403 deaths; yet, in 2012, it increased to 65,725 cases with an incidence rate (IR) of 27.67 (cases/100,000 persons), higher than the national target IR of 20.0. The Intergovernmental Panel on Climate Change (IPCC) has predicted that shortly, dengue fever incidence should increase [1].

Dengue fever occurrences in the Central Java Province of Indonesia increased during 2011 2013. In 2011, the IR was 15.26 (cases/100,000), with 46 deaths or 4.948 dengue fever occurrences causing death to 46 people (CFR $=0.76 \%$ ). In
2013, there was an IR of 45.53, and 15,144 dengue fever occurrences causing death to 183 people $(\mathrm{CFR}=1.21 \%)$ [2].

The dengue fever IR of Semarang is the highest in Central Java. Semarang's dengue fever IR from 2006 - 2013 was higher than the IR in Central Java and nationwide. In 2013, for instance, Semarang's IR was two times higher than Central Java, recorded as 2,364 occurrences. Compared to the previous year, there was an $89.11 \%$ increase from the 1,250 occurrences in 2012. Based on the area of occurrences, the dengue fever IR of the Tembalang Sub-district which was recorded as 218.20, which ranked the highest in Semarang after being in the $3^{\text {rd }}$ position in 2012. In 2014, Tembalang Sub-district also had the most top IR at 110.55 [3]. The increase and spread of dengue oc-

\section{How to cite:}

Martini, Hestiningsih R, Widjanarko B, Purwantisari S (2019) Resistance of Aedes as a Vectors Potential for Dengue Hemorrhagic Fever (DHF) in Semarang City, Indonesia. Journal of Tropical Life Science 9 (1): 89 - 94. doi: 
currences were likely caused by the high mobility of the population, urban development, climate change, changes in the density and distribution of population and other epidemiological factors that still require further research.

In 2014, the dengue fever IR Incidence was 92.43 , or $31.13 \%$ lower than the previous year, and CFR was $1.66 \%$. There were no DBD occurrences recorded in 17 or $9.6 \%$ of the sub-districts in 2014. The dengue fever IR of Tembalang subdistrict, 166.89, was the highest in Semarang [3].

There seem to be no differences in the proportion of dengue fever patients based on sex. For instance, in 2014, the number of dengue fever patients was 819 male patients or $50.31 \%$ and 809 female patients (49.69\%). Toddlers and youngsters are the vulnerable populations to dengue fever. The most occurrences were observed in children 5 - 9 years old, 436 occurrences or $27 \%$ of the total, and the fewest occurrences were observed in persons $>60$ years old $(0.3 \%)$ [3].

Semarang, the capital of Central Java province, has varied topography such as hills, plains, and coastal areas, with land slope ranging between $0-40 \%$ (steep) and is positioned between 0.75 to 348.00 meters above sea level. It has a total area of $373.67 \mathrm{~km}^{2}$ and comprises $1.15 \%$ of the total land area of Central Java province. Semarang has 16 sub-districts and 177 villages. Mijen sub-district $\left(57.55 \mathrm{~km}^{2}\right)$ and Gunungpati sub-district $\left(54.11 \mathrm{~km}^{2}\right)$ are the two sub-districts with the largest areas and are mostly covered with rice fields and plantations.

Semarang City has a relatively high average air temperature, with the average relative humidity of about 75\% [3]. Rainfall distribution throughout the year was with a total average of 9,891 mm per year. Average temperature measured by Climatology Station ranges from $29.9^{\circ} \mathrm{C}$ to $32.9^{\circ} \mathrm{C}$. Average relative humidity by month was $61 \%$ at the minimum and $83 \%$ at the maximum [3]. High rainfall amounts affect the availability of water for Aedes sp. larvae survival, and thus the numbers of mosquitoes available as potential disease vectors transmitting dengue virus from sick individuals to healthy [4].

The success of controlling the dengue fever mosquito vector control depends on its susceptibility to insecticides [5]. Long-term exposure to insecticides may cause lower sensitivity (higher resistance) of vectors to insecticide [6]. Marcombe
(2012) stated that there are several factors causing resistance such as practices in planting, vector control interventions, and urbanization [7]. Resistance to malathion has been reported by 1980 in Anopheles [8], Culex [9], and Aedes [10, 11]. The resistance of Aedes aegypti to DDT was first observed in Puerto Rico in 1960 [12], followed reports of resistance occurrences to 24 other kinds of insecticides in locations worldwide. Aedes albopictus has been reported to be resistant to six kinds of insecticides. Other reports also support that Ae. aegypti populations have become resistant to cypermethrin in Brazil [13, 14]. In Indonesia, Ae. aegypti's resistance to pyrethroid insecticides, namely deltamethrin and permethrin, has been reported in Bandung, Palembang and Surabaya [15], and also Semarang.

This research focused on tests for biochemical resistance, i.e., the activity of monooxygenase enzymes, which has been reported to be related to the mechanism causing the resistance of mosquitos to pyrethroid insecticides. Increasing the activities of monooxygenase enzymes in resistant insects is thought to allow them to reduce lethal dosages to sub-lethal dosage levels. Compared to a bioassay method, biochemical resistance test results are obtained faster, enabling earlier detection of resistance and determination of the possibility of cross-reactions with other insecticides [16].

\section{Material and Methods}

The research was conducted in 2015 in all administrative villages in Semarang. Mosquito identification to species was confirmed in Laboratory of Entomology Faculty of Public Health Diponegoro University and resistance tests were conducted in Laboratory of Research and Development of Vectoral Disease Banjarnegara District, Indonesia.

The present study was observational research supported by the cross-sectional survey approach. This study was preceded by conducting spot surveys in the study area. The variables measured were vector density, vectors species, resistance status based on the biochemical test, and distribution of resistance status based on endemicity areas in the villages in Semarang. The samples of the research were mosquitoes captured through their eggs, caught by using ovitraps. Ovitraps were placed in 15-20 houses in each village in Semarang, indoor and outdoor the houses. Ovitrap used 
this study to collect the mosquitoes’ eggs. Ovitrap was made from a plastic bottle and used an attractant. The solution of attractant was hay infusion with a concentration of $10 \%$. Besides that, mosquitoes were also trapped by larvae surveys similarly the ovitrap method. Vector density was measured through the ovitraps, then tested biochemically for the resistance level of the vectors to pyrethroid. The mosquitos observed in the resistance test were the eggs obtained from the ovitrap survey and larval survey, which were then reared to mosquitos. The vector resistance status was tested using biochemical assays.

The procedure of biochemical assay referred to the research before [17]. Mosquito samples were homogenized individually in 200 phosphate buffers (pH 7.4). As many as $20 \mu \mathrm{L}$ aliquots of the homogenate of each mosquito were included in the well microplate, then added 80 phosphate buffer. In each well the $200 \mu \mathrm{L}$ substrate TMB and $25 \mathrm{H}_{2} \mathrm{O}_{2} 3 \%$ solutions were added, then incubated for 2 hours at room temperature. The response color produced at each well was measured using the microassay reader (a wavelength of $630 \mathrm{~nm}$ ). Cut off point the Optical Density (OD) to determine the resistant mosquitoes status was $>0.165$. The data obtained from the laboratory test were analyzed with descriptive statistics.

\section{Results and Discussion}

The survey was conducted in 43 villages in Semarang which consist of endemic areas (33 villages), sporadic areas (9 villages), and potential areas (1 village). In each village, $10-15$ houses were observed. When the research was conducted it was seen that high density of vectors was observed based on entomological indicators exceeded the standards for ABJ, House Index (HI), Container Index (CI) and Breteau Index (BI). The larva-free index was recorded low at $30-50.6 \%$ or HI $49.4-70 \%$ (Table 1 ).

Vector density was related to the available breeding media in the research locations. During a larval survey in 43 samples of villages, in endemic, sporadic, and potential areas, a clear description of Aedes sp. vector breeding media. The highest number of larva were found in standing water in outdoor bathtubs; besides this, loggerheads (a place to store water) and buckets were the most common containers where larva was found. Mosquitos can also breed in media that are not
Table 1 . Vector density based on entomological indicators in Semarang

\begin{tabular}{ccccc}
\hline $\begin{array}{c}\text { Area of } \\
\text { endemicity }\end{array}$ & $\begin{array}{c}\text { ABJ } \\
(\%)\end{array}$ & $\begin{array}{c}\text { HI } \\
(\%)\end{array}$ & $\begin{array}{c}\text { CI } \\
(\%)\end{array}$ & $\begin{array}{c}\text { BI } \\
(100 \text { houses })\end{array}$ \\
\hline Endemic & 45.8 & 54.2 & 24.8 & 76.9 \\
Sporadic & 50.6 & 49.4 & 23.3 & 59.5 \\
Potential & 30.0 & 70.0 & 29.1 & 70.0 \\
\hline
\end{tabular}

used to store water for drinking or other uses, such as coconut shells, cans, wastebaskets, old tires, flower vases, bird baths, dispensers, refrigerators, and unmaintained pools.

The results confirm that vector density in Semarang is very high, in accord with other studies measuring vector density in Semarang. Mosquito density was measured by various indices like ABJ or $\mathrm{HI}, \mathrm{CI}$, and $\mathrm{BI}$, measured as $30-50.6 \%$, $49.4-$ $71.1 \%, 23.3-29.2 \%$, and $59.5-76.9$ (per 100 houses), respectively. Dengue virus vector control has been used, yet the result is not satisfactory since it has not been implemented optimally by the community. The community has to be aware that it is community-based prevention, meaning that the control is conducted by the community for the community itself to control health problems in the environment. Since community awareness is considered low, some approaches need to be done creatively.

Pre-adult Aedes sp. obtained from rearing the larva sampled during the larval survey and ovitraps were used in resistance test. Adult mosquitos used in the resistance test were 278 mosquitos and Ae. aegypti has the most number (96.8\%). Samples of adult mosquitoes obtained from pre-adult egg or larval stages represented positive containers in each target village. The number of Ae. albopictus obtained was very limited because of the dominance of Ae. aegypti in the ovitrap survey and larval survey results. From 278 mosquitos tested, $77.8 \%$ were resistant to pyrethroid and $22.2 \%$ were susceptible. Ae. aegypti resistance occurs in both female and male genders, while Ae. albopictus was more resistant in the group of female mosquitoes $(100 \%)$ than in the group of males (Table 2). If compared based on the percent resistance, more Ae. albopictus are resistant compared to Ae. aegypti. The OD was used to determine the resistant mosquitoes status. Ae. aegypti called resistance if OD showed more than 0.165 based on the biochemical test. This study 
Table 2. Aedes sp. resistance status to pyrethroid-based on biochemical test

\begin{tabular}{clccccccc}
\hline \multirow{2}{*}{ Species } & & \multicolumn{2}{c}{ Susceptible } & \multicolumn{2}{c}{ Resistant } & \multirow{2}{*}{ Total } & \multirow{2}{*}{$\%$} \\
\cline { 3 - 6 } & & $\mathrm{f}$ & $\%$ & $\mathrm{f}$ & $\%$ & & \\
\hline \multirow{2}{*}{ Ae. aegypti } & Male & 35 & 26.1 & 99 & 73.9 & 134 & 48.7 \\
& Female & 27 & 20.3 & 106 & 79.7 & 133 & 48.4 \\
\hline \multirow{2}{*}{ Ae. albopictus } & Male & 0 & 0.0 & 6 & 100.0 & 6 & 2.2 \\
& Female & 1 & 50.0 & 1 & 50.0 & 2 & 0.7 \\
\hline
\end{tabular}

just used the biochemical analysis for pyrethroid insecticide. We have not yet tested toward organophospat insecticide, and also WHO diagnostic by using impregnated paper.

Attempts to the eradication of mosquito larvae by removing sources of standing water are more important than chemical control. Extensive usage of insecticides results in vector resistance and making it more challenging to eradicate dengue fever. Although others have replaced the use of ineffective insecticide, resistant mosquito populations remain, however. According to others research extensive and, long-term insecticide usage toward targeted species might result in the selection of populations capable of developing resistance faster. In other words, susceptible insects will become less prevalent than resistant ones [18, 19]. This will result in the insect population which is dominated by insects that are resistant to applied insecticides.

There were many studies affirming the resistance of some species. Shinta et al. (2008) reported that the population of Ae. aegypti in five areas of Greater Jakarta and Bogor are resistant to 0.8\% malathion [20]. Studies in Mampang Prapatan and Tanjung Priok also report on resistant mosquitos [21]. Resistance to malathion was also found in Purbalingga, Kendal, Grobogan, and Semarang [3]. This study also affirms that $77.8 \%$ of 278 Aedes sp. sampled were resistant. Resistance tests on dengue virus mosquito vectors should be done before the application of certain insecticides.

Resistant mosquitos tested by the biochemical test can be identified from monooxygenase enzymes. An increase of monooxygenase enzyme activity can be an indicator that the mosquito is resistant to insecticides especially pyrethroids. Resistance occurs because of the enzyme activity that blocks insecticide from reaching the target site.
Monooxygenases are some of the enzymes involved in the metabolism of xenobiotic (toxic compounds) in insects, which might confer insect resistance to insecticides. The impact of monooxygenase enzymes in insect resistance to synthetic pyrethroid compounds has been studied in various species of insect vectors, such as Anopheles gambiae, which is resistant to permethrin and deltamethrin in Africa, and Ae. aegypti, which is resistant to permethrin and deltamethrin in Mexico and Thailand [22].

Ae. aegypti resistance to lambda-cyhalothrin $0.05 \%$, and $0.05 \%$ permethrin was reported in 2010 [5] and to permethrin, $0.25 \%$ was reported in 2013 in Semarang [3]. If the insects have proven to be resistant, it is necessary to use an insecticide rotation. The use of the same type of insecticides on an ongoing basis will not effectively control the resistance of mosquito populations. Substitution for insecticides types and methods for vector control should be carried out within a maximum of 2 -3 years or $4-6$ application times [15].

Monooxygenase enzyme is also known as cytochrome P450. The enzyme has an important role in metabolism, especially of endogenous substances like hormon2es, fatty acids, and steroids. Besides that, the enzyme also has a role in catabolic and anabolic reactions of poisonous substances (xenobiotic) like pesticides and other poisons in plants. Monooxygenase enzymes can perform the detoxification process of insecticides of pyrethroid types and are also involved in bioactivation reactions and insecticide detoxification from organophosphate types [23]. The increased activity of the enzyme in resistant Aedes sp. is probably caused by exposure to synthetic pyrethroid insecticide groups either used by the program (Semarang Department of Health) or community.

Semarang had high larval density based on House Index $(\mathrm{HI})=49.4-71.1 \%$, Container Index 
$=23.3-29.1 \%$, and Breteau Index $=59.5-76.9$. The index means that Semarang has a high risk of transmission of the dengue virus. Ae. albopictus is commonly found in Semarang, especially in areas used for farming. The resistance of Aedes sp. to pyrethroid was $77.8 \%$ from 278 mosquitos tested biochemically, based on monooxygenase enzyme observation. Ae. aegypti and Ae. albopictus have proven resistant to pyrethroid. Dengue fever prevention education for the community is still needed, especially during the transmission season or at the beginning of the rainy season, with emphasis on bionomic vector aspects, not only $A e$. aegypti but also Ae. albopictus.

\section{Conclusion}

Semarang had high larval density based on House Index $(\mathrm{HI})=49.4-71.1 \%$, Container Index $=23.3-29.1 \%$, and Breteau Index = 59.5 - 76.9. The index means that Semarang has a high risk of transmission of dengue virus. Ae. albopictus is commonly found in Semarang, especially in areas used for farming. The resistance of Aedes sp. to pyrethroid was $77.8 \%$ from 278 mosquitos tested biochemically, based on monooxygenase enzyme observation. Ae. aegypti and Ae. albopictus have proven resistant to pyrethroid. Dengue fever prevention education for the community is still needed, especially during the transmission season or at the beginning of the rainy season, with emphasis on bionomic vector aspects, not only $A e$. aegypti but also Ae. albopictus.

\section{Acknowledgment}

The gratitude goes to the Faculty of Public Health Diponegoro University for financial support during this study, the Department of Health for consent forms and survey respondents who participated in this study.

\section{References}

1. Mc Michael AJ, Champbell-Lendrum DH, Corvalan CF et al. (2003) Climate change and human health risk and response. Geneva, WHO.

2. Sunaryo (2013) Peta kerentanan vektor demam berdarah dengue Aedes aegypti di Provinsi Jawa Tengah. Banjarnegara, Balai Litbang P2B2.

3. BPS Semarang (2015) Semarang dalam angka tahun 2014. Semarang, BPS Semarang.

4. Novelina BA (2007) Habitat dan perilaku nyamuk Aedes serta kaitannya dengan kasus demam berdarah di Kelurahan Utan
Kayu Utara Jakarta Timur. Master Thesis. Bogor Institure of Agricultural.

5. Widiarti, Heriyanto B, Boewono DT et al. (2011) Peta resistensi vektor demam berdarah dengue Aedes aegypti terhadap insektisida kelompok organofosfat, karbamat dan pyretroid di Provinsi Jawa Tengah dan Daerah Istimewa Yogyakarta. Buletin Penelitian Kesehatan 39 (4): 176 - 189.

6. WHO (1995) Vector control for malaria and other mosquitoborne diseases. WHO Technical report Series No. 857. Geneva, WHO.

7. Marcombe S, Mathieu RB, Pocque N et al. (2012) Insecticide resistance in the dengue vector Aedes aegypti from Martinique: Distribution, mechanisms and relations with environmental factors. PLoS ONE 7 (2). doi: 10.1371/journal.pone.0030989.

8. Hemingway J, Ranson H (2000) Insecticide resistance in insect vectors of human disease. Annual Reviews of Entomology 45: 371 - 391. doi: 10.1146/annurev.ento.45.1.371.

9. Hemingway J, Karunaratne SH (1998) Mosquito carboxylesterases: A review of the molecular biology and biochemistry of a major insecticide resistance mechanism. Medical and Veterinary Entomology 12 (1): $1-12$.

10. Georghiou GP, Wirth M, Saume F, Knudsen AB (1987) Potential for organophosphate resistance in Aedes aegypti (Diptera: Culicidae) in the Caribbean area and neighboring countries. Journal of Medical Entomology 24 (3): 290 - 294. doi: 10.1093/jmedent/24.3.290.

11. Rawlins SC (1998) Spatial distribution of insecticide resistance in Caribbean populations of Aedes aegypti and its significance. Revista Panamericana de Salud Pública 4 (4): 243 - 251.

12. Fox I, Boike AH, Garcia-Moll I (1960) Notes on rock hole breeding and resistance of Aedes aegypti in Puerto Rico. The American Journal of Tropical Medicine and Hygiene 9 (4): 425 - 429. doi: 10.4269/ajtmh.1960.9.425.

13. da Cunha MP, Lima JB, Brogdon WG et al (2005) Monitoring of resistance to the pyrethroid cypermethrin in Brazilian Aedes aegypti (Diptera: Culicidae) populations collected between 2001 and 2003. Memórias do Instituto Oswaldo Cruz 100 (4): 441 - 444. doi: 10.1590/S0074-02762005000400017.

14. Lima EP, Paiva MH , de Araújo AP et al. (2011) Insecticide resistance in Aedes aegypti populations from Ceará, Brazil. Parasit Vectors 12: 4 - 5. doi: 10.1186/1756-3305-4-5.

15. Dirjen P2PL Ministry of Healthy (2012) Pedoman Penggunaan Insektisida (Pestisida) dalam Pengendalian Vektor. Kementerian Kesehatan RI. Jakarta, Ministry of Healthy Republic of Indonesia.

16. Lidia K, Levina E, Setianingrum S (2008) Deteksi dini resistensi nyamuk Aedes albopictus terhadap insektisida organofosfat di daerah endemis demam berdarah dengue di Palu (Sulawesi Tengah). Media Kesehatan Masyarakat 3 (2): 105-110.

17. Widiastuti D, Sunaryo, Pramestuti N, Martini M (2015) Monooxygenase activity in Aedes aegypti population in Tem- 
balang subdistrict, Semarang city. Aspirator: Journal of Vector Borne Diseases Studies 7 (1): 1 - 6.

18. Poison KA, Curtis C, Seng CM, Olson JG (2001) Susceptibility of two Cambodian populations of Aedes aegypti Mosquito larvae to Temephos During 2001. Dengue Bulletin 25: 79 - 83.

19. Tarumingkeng RC (1992) Insektisida: Sifat, mekanisme kerja, dan dampak penggunaan. Jakarta, UKRIDA Press.

20. Shinta, Sukowati S, Fauziah A (2008) Kerentanan nyamuk Aedes aegypti di Daerah Khusus Ibukota Jakarta dan Bogor terhadap insektisida malathion dan lamdachyhalodrin. Jurnal Ekologi Kesehatan 7 (1): 722 - 731.
21. Zulhasril, Lesmana SD (2010) Resistensi larva Aedes aegypti terhadap insektisida organofosfat di Tanjung Priok dan Mampang Prapatan. Majalah Kedokteran FK UKI 17 (3): 96 - 107.

22. David J, Ismail HM, Chandor-Proust A et al. (2013) Role of Cytochrome P450s in insecticide resistance: Impact on the control of mosquito-borne diseases and use of insecticides on earth. Philosophical Transactions of the Royal Society B: Biological Sciences 368(1612): 20120429. doi: 10.1098/rstb.2012.0429.

23. Scott JG (2008) Insect cytochrome P450s: Thinking beyond detoxification. Recent Advances in Insect Physiology, Toxicology and Molecular Biology 2008: 117 - 204. 